\title{
PERSPEKTIF MORFOLOGI DERIVASIONAL DAN INFLEKSIONAL PADA VERBA BERAFIK BAHASA INDONESIA
}

\author{
Ermanto \\ FBSS Universitas Negeri Padang \\ Email:ermanto_pdg@yahoo.com
}

\begin{abstract}
In many languages in the world, there are two tendencies of word formation: (1) word formation which changes the lexical identity (derivation), and (2) word formation which keeps the lexical identity (inflection). The morphology process in verbs in Indonesian is divided into affixational derivation, inflectional derivation. The affixational derivation process which derive the verb lexemes uses derivational affixes, meanwhile the affixational inflection process which derive the word forms (grammatical words) uses inflection affixes. The function of derivational affix is to derive the intransitive verbs and/or to derive the transitive verbs. The function of inflectional affix is to derive the grammatical words.
\end{abstract}

Key words: morphology process, derivation, inflection, verb, dan leksem.

\section{Pendahuluan}

Tulisanini mengkajimorfologi derivasional dan infleksional pada verba berafiks bahasa Indonesia (BI). Derivasi adalah proses pengubahan bentuk kata yang mengubah identitas, sedangkan infleksi adalah proses pengubahan bentuk kata yang tidak mengubah identitas. Hal ini bisa dipahami sebagai (1) pembentukan kata yang mengubah identitas (untuk derivasi) dan (2) pembentukan kata yang tidak mengubah identitas (untuk infleksi). Perkembangan kajian morfologi derivasional dan infleksional dalam buku-buku morfologi yang terbit akhirakhir ini mendorong penulis untuk mengkaji morfologi verba BI dari perspektif derivasi dan infleksi tersebut.

Menurut Hurford \& Heasley (1983:206), proses morfologi derivasi merupakan tiga proses yang terjadi secara simultan yakni: (1) proses morfologis, (2) proses sintaksis, (3) proses semantis. Proses morfologis (afiksasi, reduplikasi, pemajemukan) mengubah D yang menghasilkan turunan. Proses sintaksis mengubah kategori (baca: kelas kata, subkelas kata) seperti dari verba menjadi nomina, verba intransitif menjadi verba transitif. Proses semantik menghasilkan makna leksikal (leksem).

Korelasi ketiga proses tersebut (morfologis, sintaksis, semantis) yang terjadi pada afiksasi dicontohkan Hurford \& Heasley (1983:206) seperti dalam tabel 1.

Untuk lebih jelasnya, korelasi ketiga proses tersebut dijelaskan pada proses morfologi derivasional dalam bahasa Inggris seperti penurunan read $\rightarrow$ reader. Dari sudut pandang proses semantis, derivasi ini telah mengubah makna (leksem). Keduanya adalah dua leksem yang berbeda dan mengacu kepada konsep yang berbeda. Dari sudut pandang proses morfologis, derivasi ini mengubah bentuk read 
Tabel 1. Tiga Proses pada Afiksasi yang Bersifat Derivatif

\begin{tabular}{|l|l|l|l|}
\hline \multirow{2}{*}{ Example } & \multicolumn{1}{|c|}{$\begin{array}{c}\text { Morphological } \\
\text { Process }\end{array}$} & Syntactic Process & \multicolumn{1}{c|}{ Semantic Process } \\
\cline { 2 - 4 } & add suffix -ter & $\begin{array}{l}\text { change verb to } \\
\text { noun }\end{array}$ & $\begin{array}{l}\text { produce word denoting } \\
\text { an act or an activity }\end{array}$ \\
\hline laugh: laughter & add suffix -er & $\begin{array}{l}\text { change verb to } \\
\text { noun }\end{array}$ & $\begin{array}{l}\text { produce word denoting } \\
\text { an agent }\end{array}$ \\
\hline red: redness & add suffix -ness & $\begin{array}{l}\text { change adjective } \\
\text { to noun }\end{array}$ & $\begin{array}{l}\text { produce word denoting } \\
\text { a property }\end{array}$ \\
\hline
\end{tabular}

$\rightarrow$ reader dengan penambahan - er. Dari sudut pandang proses sintaksis, derivasi ini mengubah kategori sintaksis yakni mengubah $\mathrm{V}$ (read) $\rightarrow \mathrm{N}$ (reader).

Selain itu, Radford, dkk, (1999:167) mengemukakan beberapa contoh morfologi derivasional dalam bahasa Inggris seperti berikutini.

Berdasarkan tabel 2, Radford mengemukakan bahwa proses derivasi dalam bahasa Inggris terjadi baik dengan perubahan kelas kata ataupun tanpa perubahan kelas kata. Proses derivasi dari N bisa menghasilkan: (1) leksem nomina seperti $B O Y(\mathrm{~N}) \rightarrow B O Y H O O D$ (N), (2) leksem verba seperti MOTOR (N) $\rightarrow$ MOTORISE (V), (3) leksem adjektiva seperti CHILD (N) $\rightarrow$ CHILDISH (A). Proses derivasi dari V bisa menghasilkan: (1) leksem nomina seperti PRINT (V) $\rightarrow$ PRINTER (N), (2) leksem verba seperti WRITE (V) $\rightarrow$ REWRITE (V), (3) leksem adjektiva seperti $R E A D(\mathrm{~V}) \rightarrow R E A D A B L E$ (A). Proses derivasi dari A bisa menghasilkan: (1) leksem nomina seperti $S A D(A) \rightarrow S A D$ $N E S S(\mathrm{~N}),(2)$ leksem verba seperti $S H O R T$ (A) $\rightarrow$ SHORTEN (V), (3) leksem adjektiva seperti HAPPY (A) $\rightarrow$ UNHAPPY (A).

Kadangkala, pada sebuah kata (baca: leksem) bisa terdapat beberapa afiks seperti pada indechiperability. Pada kata yang demikian, beberapa afiks mengimbuh secara berurutan (hierarkis). Menurut Radford dkk. (1999:163), hierarki pengimbuhan afiks tersebut adalah dari $\mathrm{N}$ cipher menjadi $\mathrm{V}$ decipher; dari V de-cipher menjadi A de-cipherable; dari Ade-cipher-able menjadi A negatif in-de-cipher-able; dari Anegatif in-de-cipherable menjadi N in-de-cipher-able-ity. Hierarki penurunan kata dengan beberapa afiks derivasi itu dikemukakan Radford dkk. (1999:163) pada tabel 2.

Tabel 2. Bentuk-bentuk Derivasi dalam Bahasa Inggris Menurut Radford,dkk (1999)

\begin{tabular}{|l|l|l|l|}
\hline \multirow{2}{*}{ Dasar } & \multicolumn{3}{c|}{ Bentuk derivasi } \\
\cline { 2 - 4 } & \multicolumn{1}{c|}{ Nomina } & \multicolumn{1}{c|}{ Verba } & \multicolumn{1}{c|}{ Adjektiva } \\
\hline Nomina & boy-hood & motor-ise & child-ish \\
\hline Verba & print-er & re-write & read-able \\
\hline Adjektiva & sad-ness & short-en & un-happy \\
\hline
\end{tabular}


a. [N cipher]

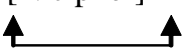

b.

[V de [N cipher] ]

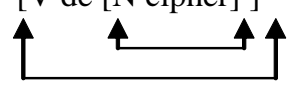

C.

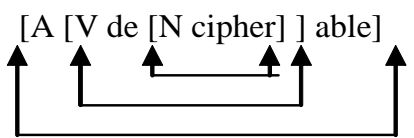

d.

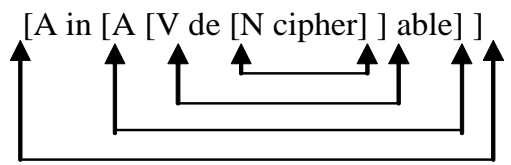

e.



Berkaitan dengan morfologi derivasional, Beard (2001:56) juga mengemukakan empat tipe derivasi yakni: (1) featural derivation (derivasi fitur), (2) fungtional derivation (derivasi fungsi), (3) tranposition (transposisi), dan (4) expressive derivation (derivasi ekspresi). Pertama, derivasi fitur adalah derivasi yang tidak mengubah kategori $\mathrm{D}$, tetapi mengoperasikan nilai-nilai fitur inheren. Kedua, derivasi fungsi (disebut juga derivasi leksikal) adalah derivasi yang menambahkan fitur pada $\mathrm{D}$, sehingga kata turunan itu berbeda secara semantis dari D. Ketiga, transposisi adalah derivasi yang mengubah kategori (kelas kata) seperti $\mathrm{V} \rightarrow \mathrm{N}$ (walk $\rightarrow$ walk-ing), $\mathrm{A} \rightarrow \mathrm{N}$ (new $\rightarrow$ new-ness), $\mathrm{N} \rightarrow$ A (budget $\rightarrow$ budget-ary). Keempat, derivasi ekspresi adalah derivasi yang tidak mengubah wilayah referensi inputnya, dan juga tidak mengubah kategori $\mathrm{D}$, tetapi memperlihatkan perbedaan nuansa makna ekspresinya. Derivasi ekspresi ini dalam bahasa Rusia seperti tiga golongan untuk 'hujan' yakni dozd, dozdik, dan dozdic-ek, dan semuanya mengacu pada konsep yang sama.

Seperti dijelaskan sebelumnya, proses morfologi derivasional adalah proses yang mengubah fitur makna leksikal. Untuk fitur makna leksikal ini, Tadjuddin (2005:32-35) mengemukakan istilah makna aksionalitas sebagai kategori leksiko-gramatikal (morfologi derivasional), bersifat tertutup, dan menghasilkan makna leksikal. Hal ini sesuai pula dengan Boiij (2005:135) yang menyatakan bahwa aspek predikasional (aspek leksikal dan diacu aktion-sart dalam bahasa Jerman) adalah aspek yang ditentukan oleh verba seperti interpretasi duratif; dan dihasilkan oleh morfologi derivasi. Menurut Boiij (2005:135) lagi, aspek predikasional ini (Tadjuddin menyebut makna aksionalitas) berbeda dengan aspek gramatikal dalam infleksi seperti perfective dan imperfective.

Demikian pula, proses morfologi infleksi dalam bahasa-bahasa di dunia dikenal dengan konjugasi dan deklinasi. Konjugasi adalah alternasi infleksi pada verba, dan deklinasi adalah alternasi infleksi pada nomina dan pada kelas kata lain seperti pronomina dan adjektiva (Verhaar, 1999:121). Konjugasi (infleksi pada verba) mencakup: (1) kala, (2) aspek, (3) modus, (4) diatesis, (5) persona, jumlah, dan jenis menurut Verhaar (1999:126).

Kelima hal itu dijelaskan Verhaar (1999: 126-133) sebagai berikut. Kala adalah hal yang menyangkut waktu atau saat (dalam hubungannya dengan saat penuturan) adanya atau terjadinya atau dilaksanakannya apa yang diartikan oleh verba seperti kala kini, lampau, dan futur. Aspek menyangkut salah satu segi dari apa yang diartikan oleh verba yaitu: adanya kegiatan atau kejadian (statif), mulainya (inkoatif), terjadinya (pungtual), berlangsungnya (duratif/progresif), selesai tidaknya (imperfektif jika belum selesai, perfektif jika selesai), adanya hasil atau tidak (resultatif jika ada hasil, nonresultatif jika tidak ada hasil), dan adanya kebiasaan (habituatif). Modus adalah pengungkapan sikap penutur terhadap apa yang dituturkan dan secara infleksional sikap itu tampak dalam modus verbal seperti 
indikatif, subjungtif, optatif/desideratif, interogatif, negatif. Diatesis adalah bentuk verba transitif yang subjeknya dapat atau tidak dapat berperan agentif; Diatesis dibedakan sebagai aktif, pasif, dan dalam bahasa tertentu juga sebagai medial. Selain itu, banyak bahasa memarkahi verba untuk persona (pertama, kedua, ketiga), jumlah (tunggal, jamak; dual, trial, paukal), jenis (maskulin, feminin, atau juga neutrum).

Selain Verhaar, para ahli yang juga mengemukakan kategori infleksi pada verba adalah berikut ini. Beberapa kategori morfologi infleksional menurut Bauer (1988:74) yakni number, person, gender, tense, aspect, voice. Hatch and Brown (1995:225) dan Widdowson (1997:49) juga menyatakan berbagai proses penurunan verba yang tergolong dalam kategori morfologi infleksional adalah: (1) tense: present, past, future, (2) voice: aktif, pasif, (3) mood: indikatif, subjungtif, imperatif. Tiga kategori morfologi infleksi untuk verba tersebut juga dinyatakan oleh Radford dkk. (1999:154-156) yakni tense, voice, dan mood. Stump (2001:28-30) mengemukakan kategori infleksi pada verba yakni tense (past, present, future), aspect, voice dan mood. Set afiks verba lainnya yang termasuk kategori infleksi verba adalah person, number, gender. Boiij (2005:100,133-140) menyatakan dalam banyak bahasa terdapat kategori penting infleksi pada verba yakni tense (past, present, future), aspect (perfective, imperfective, etc), mood (indicative, subjunctive, imperative, etc), voice (active, passive, etc), number (singular, plural, etc.), person (first, second, third), dan gender

Perbandingan beberapa pendapat pakar tentang kategori infleksi pada verba yang dikemukakan di atas dapat dilihat pada tabel 3 .

Berdasarkan pendapat Verhaar (1999), Bauer (1988), Widowson (1997), Radford, dkk. (1999), Stump (2001b), dan Boiij (2005) di atas, disimpulkan bahwa kategori infleksi pada verba adalah: (1) tense, (2) aspect, (3) mood, (4) voice, (5) person, (6) number, (7) gender.

Selain itu, dalam bahasa tertentu terdapat pula kategori infleksi dari segi ragam bahasa. Kategori infleksi ini dilihat berdasarkan pragmatik (kontekstual). Kiefer (2001:274) mengemukakan dalam bahasa Hungaria pemilihan sufiks infleksi mempunyai konse-

Tabel 3. Kategori Infleksi pada Verba Menurut Beberapa Pakar

\begin{tabular}{|l|l|l|l|l|l|l|l|}
\hline \multicolumn{1}{|c|}{ Pakar } & \multicolumn{7}{c|}{ Kategori Infleksi pada Verba } \\
\hline $\begin{array}{l}\text { Verhaar } \\
(1999)\end{array}$ & kala & aspek & modus & diatesis & persona & jumlah & jenis \\
\hline $\begin{array}{l}\text { Bauer } \\
(1988)\end{array}$ & tense & aspect & - & voice & person & number & gender \\
\hline $\begin{array}{l}\text { Widowson } \\
(1997)\end{array}$ & tense & - & mood & voice & - & - & - \\
\hline $\begin{array}{l}\text { Radford } \\
(1999)\end{array}$ & tense & - & mood & voice & - & - & - \\
\hline $\begin{array}{l}\text { Stump } \\
(2001 b)\end{array}$ & tense & aspect & mood & voice & person & number & gender \\
\hline Boiij (2005) & tense & aspect & mood & voice & person & number & gender \\
\hline
\end{tabular}


kuensi stilistik. Makna stilistik sufiks berada dalam rentangan ragam tidak formal ke ragam formal. Selain itu, Boiij (2005:109) juga mengemukakan dalam bahasa Jerman adjektif atributif mempunyai dua pola infleksi kontekstual yang secara tradisional disebut: (1) infleksi lemah (weak inflection) yakni telah memiliki definite article) dan infleksi kuat (strong inflection) yakni yang simpel/sederhana. Infleksi lemah adalah bentuk yang kurang formal (tidak formal), sedangkan infleksi kuat adalah bentuk yang formal secara kontekstual. Hal itu dicontohkan Boiij (2005:109) berikut ini.

A atributif(infleksi kuat/lebih formal)

$\begin{array}{ll}\text { heiss-er Tee } & \text { 'hot tea' } \\ \text { heiss-e Suppe } & \text { 'hot soup', } \\ \text { heiss-es Wasser } & \text { 'hot water' }\end{array}$

A atributif (infleksi lemah/ tidak formal)

der heiss-e Tee 'the hot tea'

die heiss-e Suppe 'the hot soup'

das heiss-e Wasser 'the hot water'

Berdasarkan uraian tentang morfologi derivasional dan infleksional di atas, dalam tulisan ini akan dikaji "bagaimana morfologi verba afiksasi bahasa Indonesia ditinjau dari dari perspektif morfologi derivasional dan infleksional tersebut?"

\section{Morfologi Derivasional pada Verba Afiksasi BI}

Morfologi derivasional pada verba BI adalah proses morfologi yang mengubah identitas leksikal seperti pengubahan kelas kata atau tidak mengubah kelas kata, tetapi mengubah fitur-fitur semantisnya. Perbedaan fitur semantis juga mengakibatkan perbedaan acuannya atau referennya. Hal ini menunjukkan perbedaan identitas leksikalnya.

Dalam BI, salah satu penurunan V adalah dengan afiksasi, reduplikasi, dan pemajemukan. Bahkan, Alieva, dkk. (1991:107) menyatakan bahwa afiksasi adalah cara yang pokok untuk menurunkan kata dalam BI. Demikian juga Tampubolon(1979:2) menyatakan bahwa afiksasi adalah mekanisme fundamendal (dasar) untuk menurunkan kosakata BI.

Dalam tata bahasa BI, kata tidak dibedakan antara kata dalam pengertian kata leksikal (leksem) dengan kata dalam pengertian kata gramatikal. Dengan perspektif morfologi derivasional dan infleksional, verba afiksasi BI perlu dipahami sebagai kata dalam pengertian kata leksikal (leksem), dan atau kata dalam pengertian kata gramatikal. Pemahaman ini perlu untuk menjelaskan afikasi derivasional dan afiksasi infleksional. Dalam BI, verba seperti mengangkat, diangkat, berangkat, memberangkatkan, diberangkatkan sering dipahami sebagai lima kata yang berbeda. Pemahaman ini benar dari pengertian kata secara gramatikal, dan atau secara ortografis/ fonologis. Namun, dengan pengertian kata leksikal (leksem), kelima verba itu hanya merupakan tiga kata (leksem) yakni angkat, berangkat, berangkatkan (ANGKAT, BERANGKAT, BERANGKATKAN). Verba mengangkat, diangkat adalah dua kata dari pengertian kata gramatikal, tetapi hanya satu kata (leksem) ANGKAT dari pengertian kata leksikal. Demikian juga, verba memberangkatkan, diberangkatkan adalah dua kata dari pengertian kata gramatikal, tetapi hanya satu kata (leksem) BERANGKATKAN dari pengertian kata leksikal.

Pada verba afiksasi, keberadaan afiks derivasional sangat berbeda dengan afiks infleksional. Secara semantis, afiks derivasi adalah afiks yang menyatu dengan D dalam rangka membentuk leksikal (leksem), sedangkan afiks infleksi adalah afiks yang tidak menyatu dengan D karena hanya untuk membentuk kata gramatikal tertentu. Konsekuensinya adalah afiks derivasional tidak bisa dilesapkan atau diganti oleh afiks derivasional yang lain. Jika afiks derivasional dilesapkan atau diganti dengan afiks derivasional yang lain akan mengubah makna leksikalnya. Sebaliknya, afiks infleksional bisa dilesapkan dan atau 
diganti oleh afiks infleksional yang lain. Jika dilesapkan dan/atau diganti dengan afiks infleksional yang lain tidak akan mengubah makna leksikal tetapi hanya mengubah kategori infleksional kata gramatikal itu.

Selain itu, Verhaar (1999:194) menjelaskan afiks derivasional yang mengimbuh pada V ikut menentukan arti leksikal, dan mempengaruhi (1) valensi verba, (2) peran argumen, (3) sifat lain argumen seperti persona, jumlah, jenis, dan kasus. Hal ini berbeda dengan afiks infleksional. Verhaar(1999:194) menjelaskan afiks infleksional yang mengimbuh pada V tidak ikut menentukan arti leksikal, tetapi sebagai hasil persesuaian bentuk $\mathrm{V}$ dengan argumen, atau hasil persesuaian bentuk $\mathrm{V}$ karena pengaruh argumen.

Afiksasi derivasi transposisional yang menurunkan $\mathrm{N} \rightarrow \mathrm{V}$ dalam $\mathrm{BI}$ adalah seperti pengimbuhan prefiks $m e N$ - pada darat, laut, udara, batu $(\mathrm{N}) \rightarrow$ mendarat, melaut, mengudara, membatu (V). Afiksasi ini mengubah leksem N DARAT, LAUT, UDARA, BATU menjadi leksem $\mathrm{V}$ MENDARAT, MELAUT, MENGUDARA, MEMBATU. Demikian pula pengimbuhan prefiks ber- pada anak, buah, rumah, sepeda, sepatu (N) $\rightarrow$ beranak, berbuah, berumah, bersepeda, bersepatu (V) merupakan afiksasi derivasi transposisional. Afiksasi ini mengubah leksem $\mathrm{N} A N A K$, BUAH, RUMAH, SEPEDA, SEPATU menjadi leksem V BERANAK, BERBUAH, BERUMAH, BERSEPEDA, BERSEPATU.

Selain itu, proses derivasi transposisional ada pula yang disebut dengan proses konversi (derivasi zero). Proses konversi adalah proses penurunan kata (misalnya $\mathrm{N} \rightarrow \mathrm{V}$ ) tanpa mengubah bentuk pada $\mathrm{D}$; dan konversi juga diacu sebagai derivasi zero dan proses morfologis ini disebut menggunakan morfem zero (afiks zero) (lihat Katamba, 1993:54-55; dan Bauer, 1983:32). Berkaitan dengan hasil proses konversi ini, Ophuijsen (1983:117) menyatakan bahwa dalam bahasa Melayu terdapat V yang secara bentuk menjadi satu dengan kata yang bertindak sebagai N. Dalam $\mathrm{BI}$, proses konversi telah menurunkan gunting, cangkul, sabit, gergaji, kapak, sapu, jala $(\mathrm{N}) \rightarrow$ gunting, cangkul, sabit, gergaji, kapak, sapu, jala (V) atau leksem GUNTING, CANGKUL, SABIT, GERGAJI, KAPAK, SAPU, JALA. Selanjutnya, leksem $\mathrm{V}$ ini dijadikan $\mathrm{D}$ (input) untuk proses infleksi dengan kategori diatesis (aktif dan pasif) seperti menggunting, mencangkul, menyabit, menggergaji, mengapak, menyapu, menjala; digunting, dicangkul, disabit, digergaji, dikapak, disapu, dijala.

Selain itu, afiksasi derivasi transposisional yang menurunkan $\mathrm{A} \rightarrow \mathrm{V}$ dalam BI adalah seperti pengimbuhan prefiks meN-pada merah, putih, panjang, pendek, lebar, sempit (A) $\rightarrow$ memerah, memutih, memanjang, memendek, melebar, menyempit(V). Afiksasi ini mengubah leksem A MERAH, PUTIH, PANJANG, PENDEK, LEBAR, SEMPIT menjadi leksem V MEMERAH, MEMUTIH, MEMANJANG, MEMENDEK, MELEBAR, MENYEMPIT. Demikian pula pengimbuhan prefiks per- pada merah, putih, panjang, pendek, lebar, sempit (A) $\rightarrow$ permerah, perputih, perpanjang, perpendek, perlebar, persempit (V) merupakan afiksasi derivasi transposisional. Afiksasi ini mengubah leksem A MERAH, PUTIH, PANJANG, PENDEK, LEBAR, SEMPIT menjadi leksem V PERMERAH, PERPUTIH, PERPANJANG, PERPENDEK, PERLEBAR, PERSEMPIT. Selain itu, pengimbuhan sufiks -kan pada merah, putih, panjang, pendek, lebar, sempit (A) $\rightarrow$ merahkan, putihkan, panjangkan, pendekkan, lebarkan, sempitkan (V) merupakan afiksasi derivasi transposisional. Afiksasi ini mengubah leksem A MERAH, PUTIH, PANJANG, PENDEK, LEBAR, SEMPIT menjadi leksem V MERAHKAN, PUTIHKAN, PANJANGKAN, PENDEKKAN, LEBARKAN, SEMPITKAN.

Demikian pula, afiksasi derivasi tak- 
transposisional pada $\mathrm{V}$ adalah afiksasi yang mengimbuhkan afiks derivasi pada $\mathrm{V}$ dan mengakibatkan terjadinya perubahan atau penambahan makna leksikalnya. Hal ini dapat dilihat berdasarkan perbedaan fitur semantisnya. Perbedaan fitur semantis ini berarti berbeda pula referennya dan identitas leksikalnya. Afiksasi ini tidak mengubah kelas kata, namun kadang-kadang bisa diidentifikasi perbedaan subkelas katanya. Secara semantis, afiksasi derivasi taktransposisional pada $\mathrm{V}$ akan mengubah leksem $\mathrm{V}$ menjadi leksem $\mathrm{V}$ lainnya.

Berdasarkan aspek semantisnya, V dibedakan atas beberapa subkelas. Misalnya, Chafe (1970:96-104) membedakan empat subkelas V: (1) V keadaan yakni V berfitur semantis keadaan; (2) V proses yakni V berfitur semantis proses; (3) V aksi yakni V berfitur semantis aksi, (4) V aksi proses yakni $\mathrm{V}$ berfitur semantis aksi proses. Secara sintaksis, perbedaan keempat subkelas $\mathrm{V}$ tersebut menurut Chafe adalah V keadaan membutuhkan pasien; $\mathrm{V}$ proses membutuhkan pasien; V aksi membutuhkan agen; dan V aksi proses membutuhkan agen dan pasien. Selain itu, Chafe (1970:101) juga mengemukakan adanya tipe $V$ berfitur semantis ambien yakni verba yang menyatakan keadaan meteorologi. Namun, V ambient ini dapat digolongkan ke tipe $\mathrm{V}$ proses atau V keadaan.

Selain itu, perbedaan keempat subkelas $V$ itu juga dirumuskan dengan cara pengajuan pertanyaan (lihat Chafe, 1970:98-100; dan Subroto, 2001:25) seperti berikut. V keadaan adalah $\mathrm{V}$ yang dapat menjadi jawaban pertanyaan "Subjek dalam keadaan apa?" Sesuai dengan ini, V keadaan dalam BI adalah seperti sedih, benci, cinta, sayang, rindu, bingung, takut. V proses adalah $\mathrm{V}$ yang dapat menjadi jawaban pertanyaan "Apa yang terjadi pada subjek?” Sesuai dengan ini, V proses dalam BI adalah seperti rusak, pecah, gugur, putus, patah. V aksi adalah V yang dapat menjadi jawaban pertanyaan "Apa yang dilakukan subjek?” Sesuai dengan ini, V aksi dalam BI adalah seperti lari, pergi, pulang, mandi, berangkat, bersembunyi, mendarat. $\mathrm{V}$ aksi proses adalah $\mathrm{V}$ yang dapat menjadi jawaban pertanyaan "apa yang dilakukan subjek terhadap objek?" Sesuai dengan ini, $\mathrm{V}$ aksi proses dalam BI adalah seperti mencari, membeli, makan, minum, meтukul, menghadang, menduduki, mendudukkan.

Hubungan keempat subkelas $\mathrm{V}$ itu dengan transitivitas yakni $\mathrm{V}$ keadaan, $\mathrm{V}$ proses, $\mathrm{V}$ aksi adalah $\mathrm{V}$ intransitif, sedangkan $\mathrm{V}$ aksi proses adalah $\mathrm{V}$ transitif. Hal ini seperti pada tabel 4.

Dalam BI, dengan pengajuan pertanyaan di atas kadangkala sulit membedakan subkelas. Misalnya, dengan pengajuan pertanyaan tersebut, kata tidur (TIDUR) dalam kalimat "Ia tidur" bisa diidentifikasi sebagai V keadaan atau $\mathrm{V}$ aksi. Kata tidur (TIDUR) bisa menjadi jawaban pertanyaan "Subjek dalam keadaan apa?” yakni Subjek dalam keadaan tidur; atau menjadi jawaban pertanyaan "Apa yang dilakukan subjek?”, dan jawabannya tidur.

Tabel 4. Hubungan Subkelas V Chafe dengan Transitivitas

\begin{tabular}{|l|l|l|l|}
\hline No & Subkelas verba & Transitivitas & Peran semantis/fungsi \\
\hline 1 & Verba keadaan & Verba intransitif & pasien=S \\
\hline 2 & Verba proses & Verba intransitif & pasien=S \\
\hline 3 & Verba aksi & Verba intransitif & agen=S \\
\hline 4 & Verba aksi proses & Verba transitif & agen=S, pasien=O \\
\hline
\end{tabular}


Selain itu, perbedaan antara V keadaan dengan V proses juga tidak jelas, karena dalam sintaksis, kedua tipe $\mathrm{V}$ ini sama-sama memiliki peran semantis pasien.

Dengan demikian, keempat subkelas V Chafe di atas perlu dimodifikasi sesuai dengan keadaan verba BI. Berdasarkan subkelas V yang dikemukakan Chafe dan keadaan verba $\mathrm{BI}$, subkelas verba BI dimodifikasi menjadi: (1) V keadaan (V keadaan dan $\mathrm{V}$ keadaan perasaan), (2) V peristiwa, (3) V perbuatan, (4) V tindakan. Keempat subkelas $\mathrm{V}$ ini dijelaskan dengan fitur-fitur semantis seperti pada tabel 5 .

Artinya, walaupun kadangkala peran semantis $\mathrm{V}$ keadaan sama dengan $\mathrm{V}$ peristiwa seperti kata ada (ADA) dengan pecah (PECAH) yakni sama-sama memiliki peran semantis objektif, tetapi keduanya berbeda identitas leksikalnya. Leksem $A D A$ mengacu pada 'situasi', sedangkan $P E C A H$ mengacu pada 'proses'. Hal ini dapat dilihat berdasarkan perbedaan fiturnya yakni kata ada (ADA) berfitur 'keadaan, situasi, objektif' sedangkan kata pecah (PECAH) berfitur 'kejadian, proses, objektif'. Untuk V peristiwa juga dibedakan yakni $\mathrm{V}$ peristiwa yang terjadi pada entitas tidak bernyawa dan entitas bernyawa.
Jika $V$ peristiwa itu terjadi pada entitas tidak bernyawa (seperti (Gelas itu) jatuh), maka fiturnya adalah 'kejadian, proses, objektif'. Sebaliknya, jika V peristiwa itu terjadi pada entitas bernyawa seperti (Adik) jatuh, maka fiturnya adalah 'kejadian, proses, pengalami'. Demikian pula, pada V keadaan perasaan seperti takut, rindu dalam kalimat: Dia takut pada gurunya; Ardi rindu pada istrinya, maka dia dan Ardi berperan sebagai pengrasa. Hal ini dapat dibedakan dengan $\mathrm{V}$ peristiwa seperti patah, putus dalam kalimat: Kaki orang itu patah; Talinya putus, maka kaki orang itu dan talinya berperan sebagai objektif.

Berdasarkan subkelas V di atas, bisa dijelaskan afiksasi derivasi taktransposisional pada $\mathrm{V}$ bisa mengubah subkelas $\mathrm{V}$ keadaan, $\mathrm{V}$ peristiwa, $\mathrm{V}$ perbuatan menjadi $\mathrm{V}$ tindakan (Vintr $\rightarrow$ Vtr) seperti ada, pecah, pulang (Vintr) $\rightarrow$ adakan, pecahkan, pulangkan (Vtr), atau sebaliknya mengubah V tindakan menjadi V perbuatan (Vtr $\rightarrow$ Vintr) seperti angkat, ajar (Vtr) $\rightarrow$ berangkat, belajar (Vintr). Selain itu, afiksasi derivasi taktrans-posisional pada $\mathrm{V}$ juga bisa menambahkan semantis tertentu yakni 'benefektif', 'direktif', dan 'iteratif' seperti beli $(\mathrm{V}$ tindakan) $\rightarrow$ belikan ( $\mathrm{V}$ tindakan

Tabel 5. Subkelas Verba BI

\begin{tabular}{|l|l|l|l|l|}
\hline No & \multicolumn{1}{|c|}{ Subkelas verba } & \multicolumn{1}{|c|}{ Fitur semantis } & Transitivitas & \multicolumn{1}{|c|}{$\begin{array}{c}\text { Fungsi dan Peran semantis, } \\
\text { contoh }\end{array}$} \\
\hline 1 & $\begin{array}{l}\text { Verba keadaan: } \\
\text { V keadaan }\end{array}$ & $\begin{array}{l}\text { 'keadaan, situasi, } \\
\text { objektif' } \\
\text { 'keadaan, perasaan, } \\
\text { pengrasa' }\end{array}$ & V intransitif & $\begin{array}{l}\text { S= objektif/ pengrasa } \\
\text { Ia ada di rumah. } \\
\text { Ayah cinta kepada Ani. }\end{array}$ \\
\hline 2 & Verba peristiwa & $\begin{array}{l}\text { 'kejadian, proses, } \\
\text { objektif'/ } \\
\text { 'kejadian, proses, } \\
\text { pengalami' }\end{array}$ & V intransitif & $\begin{array}{l}\text { S= objektif/ pengalami } \\
\text { Gelas itu pecah. } \\
\text { Gelas itu jatuh. }\end{array}$ \\
& & 'perbuatan, aktor' & V intransitif jatuh. \\
\hline 3 & Verba perbuatan & $\begin{array}{l}\text { S= aktor } \\
\text { Anak itu sudah pulang. }\end{array}$ \\
\hline 4 & Verba tindakan & $\begin{array}{l}\text { 'tindakan, agen, } \\
\text { pasien' }\end{array}$ & V transitif & $\begin{array}{l}\text { agen=S, pasien=O } \\
\text { Polisi (mem)-pukul penjahat. } \\
\text { Anak-anak (meng)-angkat } \\
\text { batu. }\end{array}$ \\
\hline
\end{tabular}


benefektif), tembak (V tindakan) $\rightarrow$ tembakkan (V tindakan direktif), pukul (V tindakan) $\rightarrow$ pukuli (V tindakan iteratif).

Selain itu, afiksasi ber- pada D angkat, ajar (V tindakan) berangkat, belajar (V perbuatan) adalah proses derivasi taktransposisional. Kedua kata itu memiliki makna yang berbeda dan bisa dilihat dari perbedaan fitur semantisnya yakni kata angkat, ajar (Vtr) berfitur 'tindakan, agen, pasien', sedangan kata berangkat, belajar (Vintr) berfitur 'perbuatan, aktor'. Afiksasi ini mengubah leksem ANGKAT, AJAR menjadi leksem BERANGKAT, BELAJAR.

Dalam BI, pengimbuhan afiks -kan pada D duduk, mandi, berangkat, belajar (V perbuatan) $\rightarrow$ (men)dudukkan, (me)mandikan, (mem)berangkatkan, (mem)belajarkan (V tindakan) adalah proses derivasi taktransposisional. Perbedaan makna leksikal kata-kata itu ditunjukkan oleh perbedaan fitur semantisnya. Kata duduk, mandi, berangkat, belajar (Vintr) berfitur 'perbuatan, aktor', sedangkan kata (men)dudukkan, (me)mandikan, (mem)berangkatkan, (mem)belajarkan (Vtr) berfitur 'tindakan, agen, pasien'. Jadi, afiksasi ini mengubah leksem $D U D U K$, MANDI, BERANGKAT, BELAJAR menjadi leksem MANDIKAN, DUDUKKAN, BERANGKATKAN, BELAJARKAN.

Demikian pula pengimbuhan afiks -i pada $\mathrm{D}$ datang, duduk ( $\mathrm{V}$ perbuatan) $\rightarrow$ (men)datangi, (men)duduki (V tindakan) adalah proses derivasi taktransposisional. Kata datang, duduk (Vintr) berfitur 'perbuatan, aktor' sedangkan kata (men)datangi, (men)duduki (Vtr) berfitur 'tindakan, agen, pasien'. Jadi, kata datang, duduk dengan kata (men)datangi, (men)duduki berbeda makna leksikalnya. Artinya, afiksasi ini mengubah leksem DATANG, DUDUK menjadi leksem DATANGI, DUDUKI.

Contoh lainnya proses derivasi taktransposisional dalam BI adalah pengimbuhan afiks -kan pada D hanyut, patah, hilang (V peristiwa) $\rightarrow$ (meng)hanyutkan, (me)matahkan, (meng)hilangkan (V tindakan). Katakata itu berbeda makna leksikalnya yang ditunjukkan dengan perbedaan fitur semantisnya. Kata hanyut, patah, hilang (Vintr) berfitur 'kejadian, proses, objektif/pengalami', sedangkan kata (meng)hanyutkan, (me)matahkan, menghilangkan (Vtr) berfitur 'tindakan, agen, pasien'. Afiksasi ini mengubah leksem HANYUT, PATAH, HILANG menjadi leksem HANYUTKAN, PATAHKAN, HILANGKAN.

Dalam BI, afiks - kan bisa diimbuhkan pada V tindakan (Vtr), dan afiksasi ini menambahkan makna leksikal tertentu yakni makna 'benefektif' atau 'direktif'. Misalnya, pengimbuhan afiks -kan pada D petik, ambil, bawa, beli (V tindakan) $\rightarrow$ (me)metikkan, (meng)ambilkan, (mem)bawakan, (mem)belikan (V tindakan benfektif) adalah proses derivasi taktransposisional. Kata-kata ini memiliki perbedaan makna leksikalnya yang ditunjukkan dengan perbedaan fitur semantisnya. Kata petik, ambil, bawa, beli (Vtr) berfitur 'tindakan, agen, pasien' sedangkan (me)metikkan, (meng)ambilkan, (mem)bawakan, (mem)belikan (Vtr) berfitur 'tindakan, agen, pasien benefektif, pasien objektif). Afiksasi ini mengubah leksem PETIK, AMBIL, BAWA, BELI menjadi leksem PETIKKAN, AMBILKAN, BAWAKAN, $B E L I K A N$. Hal ini sesuai pula dengan pendapat Subroto (1987:10-11) bahwa penambahan afiks -kan pada verba seperti petik akan memberikan (menambahkan) ciri semantis benefektif.

Pengimbuhan afiks - kan pada V tindakan (Vtr) juga menambahkan makna leksikal 'direktif'. Misalnya, pengimbuhan afiks -kan pada D tembak (V tindakan) $\rightarrow$ (men)tembakkan (V tindakan direktif) adalah proses derivasi taktransposisional. Kata tembak berbeda makna leksikalnya dengan kata (men)tembakkan. Kata tembak(Vtr) berfitur ‘tindakan, agen, pasien' sedangkan (men)- 
tembakkan (Vtr) berfitur 'tindakan, direktif, agen, pasien objektif, lokatif wajib). Makna direktif berkaitan dengan tindakan agen atas pasien objektif yang diarahkan/ditujukan pada lokatif wajib (lihat Dardjowidjojo, 1983: 20,90, dan Subroto 1987:11-14).

Pengimbuhan afiks -i pada $\mathrm{V}$ tindakan (Vtr) juga menambahkan makna 'iteratif'. Pengimbuhan afiks $-i$ pada V lempar $\rightarrow$ (me)lempari, petik $\rightarrow$ (mem)petiki adalah proses derivasi taktransposisional yang menambahkan ciri semantis keberkali-kalian (lihat juga Subroto, 1987:13). Jadi, kata lempar, petik (V tindakan) berbeda dengan kata (me)lempari, (mem)petiki (V tindakan iteratif). Hal ini ditunjukkan dengan perbedaan fitur semantisnya yakni kata lempar, petik berfitur 'tindakan, agen, pasien, noniteratif' sedangkan kata (me)lempari, (mem)petiki berfitur 'tindakan, agen, pasien, iteratif'. Afiksasi ini mengubah leksem LEMPAR, PETIK menjadi leksem LEMPARI, PETIKI. Tadjuddin (2005:21, 42) juga menyatakan bahwa makna iteratif merupakan jenis makna aksionalitas sebagai subkategori aspektualitas bentuk morfologi, dan makna iteratif tersebut diungkapkan dalam morfologi derivasional (leksiko-gramatikal) seperti makna iteratif afiks -i pada verba memukuli dan memotongi.

Makna iteratif pada verba itu: (1) baik dilakukan S tunggal maupun S jamak, (2) maupun ditujukan pada Otunggal maupun Ojamak (Tadjuddin, 2005). Makna iteratif yang mengacu pada S jamak disebut Tadjuddin (2005:114) dengan makna 'kooperatif', dan makna 'iteratif' yang mengacu pada O jamak disebut Tadjuddin (2005:112) dengan makna 'distributif'. Dengan demikian, afiks -i pada verba melempari, mengambili adalah bermakna 'iteratif' yang mengacu pada $\mathrm{O}$ jamak, tetapi afiks - $i$ pada verba memukuli adalah bermakna 'iteratif ‘ yang mengacu pada $\mathrm{O}$ tunggal.

Jadi, makna 'iteratif' adalah makna keberkalian yang dipandang sebagai satu kesatuan dalam makna leksikal verba itu.
Dalam hal ini, peneliti ini menyatakan bahwa makna 'iteratif' (akibat proses derivasi) berbeda dengan pluralitas verba (akibat proses $\mathrm{R}$ infleksi). Pluralitas pada verba adalah keberulangan verba yang dipandang sebagai hal yang terpisah-pisah. Artinya, makna leksikal verba tidak berubah tetapi yang terjadi adalah perulangan verba (pluralitas).

Pengimbuhan afiks ber-/-an pada D datang, (V perbuatan), jatuh (V peristiwa) $\rightarrow$ berdatangan (V perbuatan distributif), berjatuhan (V peristiwa distributif) adalah proses derivasi taktransposisional. Kata datang, jatuh berbeda makna leksikalnya dengan kata berdatangan, berjatuhan. Hal ini ditunjukkan dengan perbedaan fitur semantisnya yakni kata datang berfitur 'perbuatan, aktor, nondistributif', sedangkan kata berdatangan berfitur 'perbuatan, aktor, distributif, tidak serempak, tidak teratur'. Demikian juga kata jatuh berfitur 'kejadian, proses, objektif, nondistributif', sedangkan kata berjatuhan berfitur 'kejadian, proses, objektif, distributif, tidak serempak'. Afiksasi ini mengubah leksem DATANG, JATUH menjadi leksem BERDATANGAN, BERJATUHAN. Makna 'distributif' adalah makna ketersebaran, keberuntunan, atau keberturutan (lihat juga Tadjuddin, 2005:53, 77; Sumarlam, 2004:196). Makna 'distributif' ini berkaitan dengan perbuatan atau peristiwa pada $V$ yakni: (1) keberuntunan perbuatan (aksi) yang dilakukan oleh subjek yang beragam (subjek jamak), (2) keberuntunan peristiwa yang terjadi pada subjek yang berbagai (jamak) (lihat pula Dardjowidjojo, 1983:20).

Pengimbuhan afiks ber-pada D pulang (V perbuatan) $\rightarrow$ berpulang (V peristiwa), dan pengimbuhan afiks meN- pada $\mathrm{D}$ tinggal (V keadaan) $\rightarrow$ meninggal (V peristiwa) adalah proses derivasi taktransposisional. Makna leksikal pulang, tinggal berbeda dengan makna leksikal berpulang, meninggal. Kata pulang berfitur 'perbuatan, aktor', kata tinggal berfitur 'keadaan, situasi, 
objektif', sedangkan kata berpulang, meninggal berfitur 'kejadian, proses, pengalami'. Dengan demikian, makna kata pulang, tinggal tidak berkaitan lagi dengan makna kata berpulang, meninggal karena memilik makna baru. Alieva, dkk. (1991:130) menyatakan pengimbuhan afiks ber-, meNseperti pada V berpulang, meninggal telah mengubah arti leksikalnya.

\section{Morfologi Infleksional pada Verba Afiksasi BI}

Morfologi infleksional pada verba BI adalah proses morfologi yang tidak mengubah identitas leksikalnya. Proses morfologi infleksi ini hanya mengubah bentuk kata dan tetap beridentitas leksikal yang sama dengan $\mathrm{D}$-nya. Oleh karena tidak mengubah identitas, berarti pula proses morfologis ini tidak mengubah makna leksikalnya (tidak mengubah leksem). Hasil proses morfologi ini adalah kata gramatikal (bentuk kata) yang sesuai dengan kategori infleksi verba tersebut.

Dalam BI, afiks-afiks pembentuk verba ternyata tidak banyak yang termasuk kategori morfologi infleksional. Kategori morfologi infleksi (seperti kala, aspek, jumlah) mungkin tidak terdapat dalam verba BI, karena diungkapkan secara leksikal. Berkaitan dengan hal ini, Alieva, dkk. (1991:108) memang menyatakan bahwa pada afiksasi verba BI hanya terdapat dua kategori morfologi infleksional yakni: (1) kategori diatesis, dan (2) kategori persona. Namun demikian, sejauh tinjauan teori yang dilakukan, dalam BI kategori morfologi infleksi seperti diatesis (voice), persona, modus (mood), dan ragam perlu dikaji dalam verba $B I$.

Bentuk aktif dan bentuk pasif sebagai kategori infleksi diatesis dalam verba BI perlu ditelusuri dalam bentuk-bentuk kompleks. Verhaar (1999:118) mencontohkan, bentuk mengajar dan diajar adalah dua bentuk: bentuk aktif dan pasif (infleksi) dari kata yang sama (leksem) yaitu mengajar, sedangkan bentuk mengajar dan pengajar merupakan dua kata yang berbeda yakni verba dan nomina (derivasi). Pengertian istilah kata yang sama dengan kata yang tidak sama adalah dalam pengertian kata sebagai leksem. Jadi, menurut Verhaar (1999:147), pada bentuk-bentuk paradigmatis (infleksi) seperti mengajarnya, diajar, diajarnya, kuajar, kauajar ditentukan bentuk kutipnya mengajar. Penggunaan istilah bentuk kutip oleh Verhaar merupakan istilah yang sama dengan konsep leksem. Dengan demikian, leksem dari bentuk-bentuk paradigmatis (infleksi) mengajar, diajar, kuajar, kauajar itu adalah AJAR.

Dalam BI, beberapa afiks infleksional yang mengimbuh pada V tindakan (Vtr) yakni afiks meN- (pemarkah kategori aktif) untuk menandai S adalah agen; afiks di- (pemarkah kategori pasif) untuk menandai S adalah pasien, proklitik $k u$ - (persona pertama), dan proklitik kau-(persona kedua). Proses afiksasi infleksi ini bersifat teratur, dan teramalkan, dan terjadi pada V tindakan (Vtr) (lihat juga Subroto, 1996; 1989; 1987). Afiks (dan klitik) infleksi meN-, di-, ku-, kau- tersebut mengimbuh pada $\mathrm{V}$ tindakan(Vtr) seperti cari, pukul, beli, dorong (leksem CARI, PUKUL, BELI, DORONG) $\rightarrow$ mencari, dicari, kucari, kaucari; memukul, dipukul, kupukul, kaupukul; membeli, dibeli, kubeli, kaubeli; mendorong, didorong, kudorong, kaudorong (bentuk-kata atau kata gramatikal).

Selain itu, afiks (dan klitik) infleksional meN-, di-, ku-, kau- juga mengimbuh pada $\mathrm{V}$ tindakan (Vtr) berbentuk polimorfemis. Pengimbuhan afiks (dan klitik) infleksi meN-, di-, ku-, kau- pada V tindakan (Vtr) seperti duduki, temui, datangi, hitami (leksem DUDUKI, TEMUI, DATANGI, HITAMI) $\rightarrow$ menduduki, diduduki, kududuki, kaududuki; menemui, ditemui, kutemui, kautemui; mendatangi, didatangi, kudatangi, kaudatangi; menghitami, dihitami, kuhitami, kauhitami (bentuk-kata atau kata gramatikal). Demikian juga pengimbuhan afiks 
(dan klitik) infleksi meN-, di-, ku-, kau- pada $\mathrm{V}$ tindakan (Vtr) seperti carikan, belikan, buatkan (leksem CARIKAN, BELIKAN, BUATKAN) $\rightarrow$ mencarikan, dicarikan, kucarikan, kaucarikan; membelikan, dibelikan, kubelikan, kaubelikan; membuatkan, dibuatkan, kubuatkan, kaubuatkan (bentuk-kata atau kata gramatikal).

Dalam BI, tampaknya terdapat pula afiks infleksional yang menghasilkan bentuk kata (kata gramatikal) untuk kategori ragam formal dan tidak formal. Pengimbuhan afik ber-pada D lari, kerja (leksem LARI, KERJA) $\rightarrow$ berlari, bekerja (bentuk-kata ragam formal) yang dioposisikan dengan Ølari, Økerja (bentuk-kata ragam tidak formal) adalah proses morfologi infleksional. Hal ini sesuai dengan pendapat Alieva, dkk. (1991:130) yang menyatakan afiks ber- tidak mengakibatkan perbedaan arti leksikal (tidak berbeda maknanya). Dengan demikian, Ølari dan berlari, Økerja dan bekerja adalah tidak berbeda fitur semantisnya dan berarti pula tidak terdapat perbedaan referennya (Subroto, 1987:18). Karena itu, proses morfologui itu adalah proses morfologi infleksional.

Selain itu, pengimbuhan klitik infleksional -lah pada Vtr menurunkan Vtr bermodus hortatif (pembujukan halus). Modus hortatif dengan klitik-lah ini bisa mengimbuh secara otomatis pada semua leksem Vtr seperti $C A R I$, AMBIL, PUKUL, DORONG, LIHAT, BACA, DENGAR, TOLONG, GUNTING, POTONG, CANGKUL, $\rightarrow$ carilah $(Y)$, ambillah $(Y)$, pukullah $(Y)$, doronglah $(Y)$, lihatlah $(Y)$, bacalah $(Y)$, dengarlah $(Y)$, tolonglah $(Y)$, guntinglah $(Y)$, potonglah $(Y)$, cangkullah (Y). Modus hortatif ini adalah siasat untuk membuat orang yang disapa berbuat sesuatu dengan pembujukan halus (lihat Verhaar, 1999:257). Selain itu, pengimbuhan klitik infleksi-lah pada Vintr perbuatan menurunkan Vintr bermodus hortatif (pembujukan halus). Modus hortatif dengan klitiklah ini terjadi secara otomatis pada semua leksem Vintr perbuatan seperti DATANG, LARI, DUDUK, PERGI, PULANG, TIDUR, BICARA, BERKATA, BERBUAT, BERANGKAT, BELAJAR $\rightarrow$ datanglah, larilah, duduklah, pergilah, pulanglah, tidurlah, bicaralah, berkatalah, berbuatlah, berangkatlah, belajarlah.

\section{Simpulan}

Perbedaan utama antara proses morfologi derivasional dan infleksional adalah proses derivasional menurunkan leksem dari leksem (lain), sedangkan proses infleksional menurunkan kata gramatikal (bentuk kata) dari suatu leksem. Jadi, derivasional memproses leksem untuk menurunkan leksem, sedangkan infleksional memproses leksem untuk menurunkan kata gramatikal.

Morfologi derivasional pada verba afiksasi berfungsi menghasilkan leksem verba (turunan) untuk menyatakan berbagai makna. Artinya, morfologi derivasional merupakan cara memper-kaya leksem verba BI berdasarkan leksem yang sudah ada. Morfologi infleksional berfungsi pula untuk memperkaya bentukbentuk kata (kata gramatikal) dari suatu leksem untuk menyatakan suatu makna yang tetap. Morfologi infleksional ini adalah dalam rangka memenuhi tuntutan sintaksis sesuai dengan kategori infleksi yang terdapat pada morfologi verba BI seperti kategori diatesis, ragam, jumlah, dan modus. 


\section{DAFTAR PUSTAKA}

Alieva, N.F dkk. 1991. Bahasa Indonesia: Deskripsi dan Teori. Yogyakarta: Kanisius.

Bauer, Laurie. 1988. Introducing Linguistic Morphology. Edinburgh: Edinburgh University Press.

Bauer, Laurie. 1983. English Word Formation. Cambridge: Cambridge University Press.

Boiij, Geert. 2005. The Grammar of Words: An Introduction to Linguistic Morphology. New York: Oxford University Press.

Chafe, Wallace L. 1970. Meaning and The Structure of Language. Chicago: The University of Chicago Press.

Dardjowidjojo, Soenjono. 1983. Beberapa Aspek Linguistik Indonesia. Jakarta: Penerbit Djambatan.

Hurford, James R \& Heasley, Brendan. 1983. Semantics: a coursebook. Cambridge: Cambridge University Press.

Katamba, Francis. 1993. Morfology. London: The Macmillan Press.

Kiefer, Ferenz. 2001. "Morphology and Pragmatics” dalam Andrew Spencer and Anold M. Zwicky (eds) The Handbook of Morphology. Malden: Blackwell Publishers.

Ophuijsen, Ch. A. van. 1983. Tata Bahasa Melayu. Jakarta: Penerbit Djambatan.

Radford, Andrew dkk. 1999. Linguistic: An Introduction. Cambridge: Cambridge Unoiversity Press.

Stump, Gregory. 2001. “Inflection” dalam Andrew Spencer and Anold M. Zwicky (eds) The Handbook of Morfology. Malden: Blackwell Publishers.

Subroto, D. Edi. 2001. “Fitur-fitur Semantik Verba Bahasa Jawa” Jurnal Linguistik Bahasa. Surakarta: Program Pascasarjana UNS.

Subroto, D. Edi. 1996. “Konsep Leksem dan Upaya Pengorganisasian Kembali Lema dan Sublema Kamus Besar Bahasa Indonesia” dalam Soenjono Dardjowidjojo (Ed.) Bahasa Nasional Kita: Dari Sumpah Pemuda ke Pesta Emas Kemerdekaan 1928-1995. Bandung: Penerbit ITB Bandung.

Subroto, D. Edi. 1989. “Konsep Leksem dan Upaya Pembaharuan Penyusunan Kamus dalam Bahasa Indonesia.” Makalah Pertemuan Ilmiah Bahasa dan Sastra Indonesia XI, IKIP Muhammadyah Yogyakarta, 16-17 Oktober.

Subroto, D. Edi. 1987. “Derivasi dan infleksi : Kemungkinan Penerapannya dalam Morfologi Bahasa Indonesia.” Majalah Ilmiah Haluan Sastra dan Budaya No. 13 Tahun VII September-Oktober. Surakarta: Fakultas Sastra UNS.

Tadjuddin, Moh. 2005. Aspektualitas dalam Kajian Linguistik. Bandung: Penerbit P.T. Alumni. 
Tampubolon, dkk. 1979. Tipe-tipe Semantik Kata Kerja Bahasa Indonesia Kontemporer. Jakarta: Pusat Pembinaan dan Pengembangan Bahasa.

Verhaar, J.W.M. 1999. Asas-asas Linguistik Umum. Yogyakarta: Gadjah Mada University Press.

Widdowson, H.G. 1997. Linguistics. New York: Oxford University Press. 